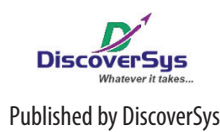

Published by DiscoverSys

\section{Alcohol consumption and risk of type 2 diabetes mellitus among males in The Manggis Area, Karangasem, Bali}

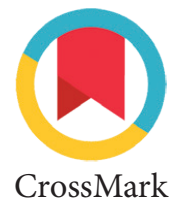

\author{
I Gusti Ayu Mirah Adhi, ${ }^{1 *}$ Ni Luh Putu Suariyani, ${ }^{2}$ \\ I Wayan Weta, ${ }^{2}$ Anak Agung Sagung Sawitri ${ }^{2}$
}

\title{
ABSTRACT
}

Background and purpose: Diabetes mellitus (DM) is a serious health problem worldwide. Local alcohol consumption is one of Balinese's traditions considered to be associated with the high incidence of DM. This study aims to determine the pattern of alcohol consumption and risk of type 2 DM in Manggis Subdistrict, Karangasem, Bali.

Methods: A case control study was conducted in 55 men with type $2 \mathrm{DM}$ as cases and 55 non-diabetic men as controls. Non-diabetic men were defined with fasting glucose level (GDP) $<100 \mathrm{mg} / \mathrm{dl}$ and without clinical symptoms of DM. Cases were recruited from the patient's register at the public health centre (PHC) in Manggis SubDistrict and controls were recruited from similar neighborhood with the cases and matched by age. Data were collected over May-July 2017 by households' interview using structured questionnaires. Multivariate analysis was employed using logistic regression to identify the risk factors of type 2 DM.
Results: The characteristics of cases and controls were similar in terms of age, education and physical activity, but there was a significant difference in employment. Multivariate analysis showed that heavy alcohol consumption ( $\mathrm{AOR}=7.84 ; 95 \% \mathrm{Cl}: 1.46-42.28)$, frequent consumption of high sugar alcohol drinks ( $A O R=3.45 ; 95 \%$ Cl: 1.16-10.22), history of obesity (AOR=8.82; $95 \%$ Cl: 2.43-32.01), employed ( $A O R=5.98 ; 95 \% \mathrm{Cl}: 1.89-18.93)$ and frequent consumption of sweetened beverages ( $A 0 R=39,57 ; 95 \% \mathrm{Cl}$ : 4.00-391,8) were significantly associated with the incidence of type $2 \mathrm{DM}$. No significant association was found between the duration of alcohol consumption and the incidence of type $2 \mathrm{DM}$.

Conclusions: Alcohol consumption, a history of obesity, consumption of high sugar alcohol drinks, retirement/unemployment and consumption of sweetened beverages are associated with the incidence of type 2 DM. Education regarding those risk factors should be enhanced to reduce the incidence of type $2 \mathrm{DM}$.

Keywords: Type 2 DM, alcohol consumption, obesity, Bali

Cite This Article: Adhi, I.G.A.M., Suariyani, N.L.P., Weta, I.W., Sawitri, A.A.S. 2018. Alcohol consumption and risk of type 2 diabetes mellitus among males in The Manggis Area, Karangasem, Bali. Public Health and Preventive Medicine Archive 6(1): 31-36. D01:10.15562/phpma.v6i1.6

\section{'STIKES Mataram,}

${ }^{2}$ Department of Public Health and Preventive Medicine, Faculty of Medicine Udayana University
*Correspondence to:

I Gusti Ayu Mirah Adhi, STIKES Mataram

gustiayumirahadhi@gmail.com

\section{INTRODUCTION}

Diabetes mellitus (DM) is a major global public health problem and $90 \%$ of all cases of diabetes in the world are DM type $2 .{ }^{1}$ The International Diabetes Federation (IDF) estimates that by 2013 the number of adults living with diabetes in the world reached 382 million. This number is expected to increase to over 592 million in less than 25 years. IDF data shows that in 2013 the proportion of diabetics in Indonesia was 8.5 million people or $4.81 \%$ of the population, therefore Indonesia ranked among the top 10 countries with the highest rate of diabetes in the world. ${ }^{2}$ The 2007 Indonesia Basic Health Research (Riskesdas) also shows that the prevalence of DM in Indonesia was greater than the IDF estimate of $5.7 \%$ or equal to 9.35 million of the total population aged $>15$ years. ${ }^{3}$ The 2013 Indonesia Basic Health Research (Riskesdas) shows an increase in the proportion of DM in Indonesia to $6.9 \%$ or equal to 12.19 million of the total population aged $>15$ years. ${ }^{4}$
Studies on DM risk factors have been conducted widely. Several studies have shown that there are risk factors, which cannot be modified including genetics, age, sex and history of low birth weight. Other risk factors can be modified which include obesity, diet, physical activity and dyslipidemia. ${ }^{5,6,7,8,9}$ Several studies have shown that high alcohol consumption can increase the risk of DM type 2 and this risk factor can be modified. ${ }^{10,11}$ Alcohol consumption in Indonesia is arguably high, especially in rural areas. Alcoholic beverages that are often consumed in rural and village contexts are those using traditional distilling methods. ${ }^{12,13}$

According to The 2013 Indonesia Basic Health Research (Riskesdas), the prevalence of DM in Bali was $1.5 \%{ }^{4}$ Although the figure is lower than the national estimate, ${ }^{3,4}$ The 2007 Indonesia Basic Health Research (Riskesdas) indicated that Bali Province is included in 15 provinces that have a high proportion of alcohol consumption, that is 
above the national estimate. ${ }^{3}$ Karangasem, one of the eight districts in Bali, reports an increase in the prevalence of diabetics from $0.4 \%{ }^{14}$ in 2007 to $1.0 \%{ }^{15}$ in 2013. The 2007 Bali Province Basic Health Research (Riskesdas) showed that this district has the highest proportion of alcohol consumption compared to other districts, and higher than the Bali as well as national estimates. The proportion of alcohol consumption in the past 12 months in 2007 for Karangasem was $10.7 \%$ and the $1^{\text {st }}$ month was $9.1 \% .{ }^{14}$ Karangasem has eight sub-districts, one of which is Manggis. ${ }^{16}$ Data from the Karangasem Health Office indicated that most diabetic patients presented at the Manggis I Public Health Center. ${ }^{17}$ In addition, it is important to note, that this district is one of the key producers of traditional palm wine, or tuak on the island. Other than being tuak distillers, the consumption of the beverage in this area seems also high; as evidenced by a study in one of the villages indicating that at least $53.18 \%$ of the total 222 respondents had consumed tuak. ${ }^{18}$

Tuak is a traditional alcoholic beverage made by tapping the sap of the sugar palm tree. The sap is extracted and collected by a tapper and the white sappy liquid, nira that initially collects tends to be very sweet and non-alcoholic before it is fermented. A study in Indonesia ${ }^{19}$ indicated that after fermented, nira consists of water (80-90\%), sucrose (12.30-17.40\%), sugars $(0.5-1 \%)$ and other ingredients (1.5-7\%), therefore tuak can be classified as an alcoholic beverage with high sugar content. ${ }^{19}$ This study aims to identify the association between alcohol consumption, specifically tuak, and type $2 \mathrm{DM}$.

\section{METHODS}

A case control study was conducted with data collected from May to July 2017 in the Manggis Sub-District. Cases were 55 men aged $40-80$ years who were diagnosed with type $2 \mathrm{DM}$ by doctors at the Manggis Sub-District PHC, and reside in Manggis Sub-District. Controls were 55 males who had undergone blood glucose fasting (GDP) with glucose levels $<100 \mathrm{mg} / \mathrm{dl}$ and had no DM clinical symptoms. They were recruited from similar neighborhood with the case and matched by age.

Data collected were education, occupation, alcohol consumption (type, duration and amount), obesity, diet history and physical activity. Data were collected by interview in the house of respondents using a standardized questionnaire. Informed consents were obtained prior to the interviews.

Questionnaire for alcohol consumption were modified from WHO STEPs Instrument. ${ }^{20}$ Duration of alcohol consumption is categorized to be $<30$ years, and $\geq 30$ years. Among cases, the duration of alcohol consumption is determined from the first alcohol intake to the time of DM diagnosis, whereas among controls, it is determined until the time of the study. Three categories were established for the amount of alcohol consumption: non-drinkers/light drinkers ( $<0.052-1.0$ gram/day), moderate drinkers (1.14 to 5.2 gram/day) and heavy drinkers (>5.2 gram/day). The amount of alcohol consumption was obtained by converting the highest amount of alcohol consumed by type of alcoholic beverage and the frequency of consumption. Types of alcoholic drinks were categorized as high and low sugar. High sugar alcohol includes only palm wines (tuak), while the others included in the low sugar.

Diet was measured using modified Food Frequency Questionnaire (FFQ) ${ }^{21}$ Different types of food/beverages were questioned on the last 30 days of consumption. The frequency of consumption was categorised as never, 0-3 times/ month, 1-3 times/week, 4-6 times/week, 1 time/day and more than one time/day. History of diet among case group was explored before the diagnosis of DM established, while among controls explored on the last 30 days. The frequency of food consumption was grouped into rarely (0-12/month) and often. Rarely category referred to a combination of never, $0-3 \times /$ month and $1-3 x /$ week. The often category $(>12 \times /$ month) referred to a combination of three other categories: 4-6x/week, 1x/day and $>1 \mathrm{x} /$ day.

Physical activity was measured using the Global Physical Activity Questionnaire (GPAQ) which consisted of work, recreation, exercise, movement and physical inactivity. ${ }^{22}$ Physical activity was converted to metabolic equivalent (Met) value, and then calculated for 7 days using formula available in the GPAQ. It is categorized as sufficient ( $\geq 600$ Met minutes/week) and low ( $<600$ Met minutes/week).

Data analysed using STATA SE 12.1 and multivariate analysis was employed using logitic regression to identify the association between alcohol consumption with type $2 \mathrm{DM}$. Variables included in the multivariate model are those having $\mathrm{p}$ value $<0.25$ in bivariate analysis.

This study obtained Ethics Clearance by the Human Research Ethic Committee Faculty of Medicine Udayana University/Sanglah General Hospital Denpasar on May 18, 2017.

\section{RESULTS}

Table 1 presents the characteristics of cases and controls by age, education, occupation, and level of physical activity. It is showed that there is no significant difference $(p>0,05)$ between cases and controls by age, education and physical activity. However, there is a significant difference by employment $(\mathrm{p}<0.05)$. 
Table 2 shows the crude odd ratio (OR) of alcohol consumption patterns (length, type and amount of alcohol intake), employment, obesity and diet history (sweet drinks, sugar, vegetable and protein intake, use of oil and intake of fried food). Variables significantly associated with with type 2 $\mathrm{DM}$ were heavy alcohol consumption $(\mathrm{OR}=6.59$; 95\%CI:1.76-24.71), high sugar alcoholic beverages (tuak) $(\mathrm{OR}=3,11$; 95\%CI: 1.42-6.81), obesity $(\mathrm{OR}=5.87$; 95\%CI: 2.15-16), employed $(\mathrm{OR}=4.03$; 95\%CI: $1,7-9,6)$ and sweet drink consumption $(\mathrm{OR}=20,25$; 95\%CI: 2,57-159,7).

Variables with $\mathrm{p}$ value $<0.25$ was included in the multivariate analysis. Table 3 shows that variables significantly associated with type $2 \mathrm{DM}$ were heavy drinker ( $\mathrm{AOR}=7.84,95 \% \mathrm{CI}: 1.46-42.28)$, high sugar alcoholic beverage intake $(\mathrm{AOR}=3.45$; 95\%CI: $1.16-10,22)$, obesity $(\mathrm{AOR}=8.82 ; 95 \% \mathrm{CI}$ : 2.43-32.01), employed $\quad(\mathrm{AOR}=5.98 ; \quad 95 \% \mathrm{CI}$ : 1.9-18.9) and consumption of sweet drinks ( $\mathrm{AOR}=39.57$; 95\%CI: 4.0-391.8).

\section{DISCUSSION}

This study indicates that heavy alcohol drinkers, high sugar alcohol (tuak) consumption, obesity, employed and high sugar drink consumption are risk factors for type $2 \mathrm{DM}$. Our study shows that the consumption of alcohol in large amounts increases the risk of type 2 DM. A study conducted in Japan, found that men aged 35-61 years who were heavy alcohol drinkers were at risk for type 2 DM. Another study in Texas, found that the risk of type 2 DM doubled with high alcohol consumption when compared with moderate alcohol consumption.

A study in the United States showed that heavy alcohol consumption had an impact on liver damage or chronic pancreatitis, ${ }^{23}$ which could potentially lead to type $2 \mathrm{DM}$.

Our study shows that the level of tuak intake in both groups studied was high. This is consistent with two previous studies stating that traditional alcoholic drinks such as palm wine (tuak) are mostly consumed in rural areas, ${ }^{12}$ and have become part of tradition, during custom celebrations, parties and daily activities. ${ }^{13}$ In our knowledge, there is no publication in Indonesia related to the consumption of tuak or traditional alcoholic beverages and the risk of type 2 DM. Previous study related to tuak in Tegallinggah Village, Karangasem, Bali found that tuak consumption increased the risk of obesity, ${ }^{18}$ which is also known as one of the DM risk factors. Our findings are not consistent with the two previous studies in the United States wherein the type of alcoholic beverages consumed had no effect on the incidence of DM. ${ }^{24,23}$ This disparity may be due to differences in alcoholic beverages in both regions and other diverse consumption pattern characteristics.

In our study, obesity has also been shown to significantly increase the risk of type $2 \mathrm{DM}$. This finding consistent with a number of previous studies in some areas of Indonesia, namely in South

Table 1 Characteristics of cases and controls

\begin{tabular}{|c|c|c|c|c|c|}
\hline \multirow[b]{2}{*}{ Characteristic } & \multicolumn{2}{|c|}{ Cases } & \multicolumn{2}{|c|}{ Controls } & \multirow[b]{2}{*}{ p value } \\
\hline & $\mathbf{n}$ & $\%$ & $\mathbf{n}$ & $\%$ & \\
\hline \multicolumn{6}{|l|}{ Age (years) } \\
\hline $40-49$ & 2 & 3.64 & 3 & 5.45 & \\
\hline $50-59$ & 21 & 38.18 & 18 & 32.73 & \\
\hline $60-69$ & 22 & 40.00 & 26 & 47.27 & \\
\hline $70+$ & 10 & 18.18 & 8 & 14.55 & 0.805 \\
\hline \multicolumn{6}{|l|}{ Education } \\
\hline Elementary & 28 & 50.91 & 31 & 56.36 & \\
\hline Junior high school & 3 & 5.45 & 4 & 7.27 & \\
\hline Senior high school & 8 & 14.55 & 12 & 21.82 & \\
\hline University & 16 & 29.09 & 8 & 14.55 & 0.288 \\
\hline \multicolumn{6}{|l|}{ Employment } \\
\hline Retired/unemployed & 29 & 52.73 & 45 & 81.82 & \\
\hline Employed & 26 & 47.27 & 10 & 18.18 & 0.001 \\
\hline \multicolumn{6}{|l|}{ Physical activity } \\
\hline Sufficient( $\geq 600$ Met minute/week) & 51 & 92.73 & 54 & 98.18 & \\
\hline Insufficient (<600 Met minute/week) & 4 & 7.27 & 1 & 1.82 & 0.170 \\
\hline
\end{tabular}


Table 2 Crude OR of alcohol consumption, obesity, employment and diet

\begin{tabular}{|c|c|c|c|c|c|c|}
\hline \multirow[b]{2}{*}{ Variables } & \multicolumn{2}{|c|}{ Cases } & \multicolumn{2}{|c|}{ Controls } & \multirow[b]{2}{*}{ OR } & \multirow[b]{2}{*}{ p value } \\
\hline & $\mathbf{n}$ & $\%$ & $\mathbf{n}$ & $\%$ & & \\
\hline \multicolumn{7}{|l|}{ Alcohol intake/amount } \\
\hline Light $(<0,052-1,09$ gr/day $)$ & 34 & 61.82 & 48 & 87.27 & Ref. & \\
\hline Moderate (1,14-5,2 gr/day) & 7 & 12.73 & 4 & 7.27 & 2.47 & 0.174 \\
\hline Heavy (>5,2 gr/day) & 14 & 25.45 & 3 & 5.45 & 6.59 & 0.005 \\
\hline \multicolumn{7}{|c|}{ High sugar alcohol (tuak) intake } \\
\hline No & 17 & 30.91 & 32 & 58.18 & & \\
\hline Yes & 38 & 69.09 & 23 & 41.82 & 3.11 & 0.005 \\
\hline \multicolumn{7}{|l|}{ Duration of alcohol intake } \\
\hline$<30$ yrs & 21 & 38.18 & 32 & 58.18 & & \\
\hline$\geq 30$ yrs & 34 & 61.82 & 23 & 41.82 & 2.25 & 0.037 \\
\hline \multicolumn{7}{|l|}{ Obesity } \\
\hline No & & 58.18 & 49 & 89.09 & & \\
\hline Yes & 3223 & 41.82 & 6 & 10.91 & 5.87 & 0.001 \\
\hline \multicolumn{7}{|l|}{ Employment } \\
\hline Retired/unemployed & 29 & 52.73 & 45 & 81.82 & & \\
\hline Employed & 26 & 47.27 & 10 & 18.18 & 4.03 & 0.002 \\
\hline \multicolumn{7}{|l|}{ High sugar drink intake } \\
\hline Rarely (0-12x/month) & 40 & 72.73 & 54 & 98.18 & & \\
\hline Often (>12x/month) & 15 & 27.27 & 1 & 1.82 & 20.25 & 0.004 \\
\hline \multicolumn{7}{|l|}{ Sugar intake } \\
\hline Rarely (0-12x/month) & 11 & 20.00 & 21 & 38.18 & & \\
\hline Often (>12x/month) & 44 & 80.00 & 34 & 61.82 & 2.47 & \\
\hline \multicolumn{7}{|l|}{ Protein intake } \\
\hline Rarely (0-12x/month) & 46 & 83.64 & 28 & 50.91 & & \\
\hline Often (>12x/month) & 9 & 16.36 & 27 & 49.09 & 0.20 & \\
\hline \multicolumn{7}{|l|}{ Oil intake } \\
\hline Rarely (0-12x/month) & 1 & 1.82 & 7 & 12.73 & & \\
\hline Often (>12x/ month) & 54 & 98.18 & 48 & 87.27 & 7.88 & \\
\hline \multicolumn{7}{|l|}{ Fried food consumption } \\
\hline Rarely (0-12x/ month) & 1 & 1.82 & 9 & 16.36 & & \\
\hline Often $(>12 x /$ month $)$ & 54 & 98.18 & 46 & 83.64 & 10.57 & \\
\hline
\end{tabular}

Denpasar, Bali; ${ }^{7}$ in Semarang, Central Java, ${ }^{8}$ and Manado, Sulawesi. ${ }^{6}$

Employment has also been shown as a significant risk factor on type $2 \mathrm{DM}$, whereas those who are employed are more likely to develop type $2 \mathrm{DM}$. This finding is not consistent with other study in Denpasar, Bali which shows that employment was not associated with type $2 \mathrm{DM}$. $^{7}$

This study also found that the consumption of high sugar drinks is a factor that increases the risk of type $2 \mathrm{DM}$. This finding is consistent with studies in Semarang, Central Java ${ }^{8}$ and Jakarta. ${ }^{9}$
The limitations of this study is the possible information bias to recall the history of alcohol consumption which relies on the respondent's memory. In addition, the amount of alcohol consumption is determined by conversion from glass/bottle to $\mathrm{ml}$ size and then converted to gram, and there was a variation in the size of glass and bottle used by respondents. Another information bias identified was the history of obesity which was determined by interviews. This study only cover a limited area in one sub-district, thus generalization to the wider population should be taken with caution. 
Table 3 Association between some variables with type 2 DM

\begin{tabular}{lcc}
\hline Variables & Adjusted OR & $\mathbf{9 5 \%} \mathbf{C l}$ \\
\hline Alcohol intake/amount & & \\
Light (<0,052-1,09 gr/day) & 1 (Ref) & \\
Moderate (1,14-5,2 gr alcohol/day) & 5.07 & $0.98-26.15$ \\
Heavy ( $>5,2$ gr alcohol/day) & 7.84 & $1.46-42.28$ \\
High sugar alcohol intake (tuak) & & \\
No & $1($ Ref $)$ & $1.16-10.22$ \\
Yes & 3.45 & \\
Obesity & & \\
No & $1($ Ref $)$ & \\
Yes & 8.82 & \\
Employment & & $1.89-18.93$ \\
Retired/unemployed & $1($ Ref $)$ & \\
Employed & 5.98 & \\
High sugar drink intake & & $4.00-391.8$ \\
Rarely (0-12x/month) & $1($ Ref $)$ & \\
Often (>12x/month) & 39.57 &
\end{tabular}

\section{CONCLUSION}

Alcohol consumption, obesity, consumption of high sugar alcohol drinks, employment and consumption of sweetened beverages are associated with the incidence of type $2 \mathrm{DM}$. Education regarding alcohol consumption, especially the high sugar alcohol drinks in preventing type $2 \mathrm{DM}$ should be enhanced mainly in areas known to have traditional alcohol consumption habits.

\section{ACKNOWLEDGEMENT}

We would like to thank the Head of Manggis Sub-District, Manggis I and II Public Health Centers and all respondents who have participated in this study.

\section{REFERENCES}

1. Ministry of Health of Indonesia. Current situation and analysis of diabetes. Jakarta. 2014

2. Internasional Diabetes Federation. IDF diabetes atlas (Sixth Edition). 2013. Available at: https:// idf.org/e-library/epidemiology-research/ diabetes-atlas/19-atlas-6th-edition.html

3. Ministry of Health of Indonesia. Riset Kesehatan Dasar (Riskesdas) 2007 (The 2007 Indonesia Basic Health Research). Jakarta. 2008.

4. Ministry of Health of Indonesia. Riset Kesehatan Dasar (Riskesdas) 2013 (The 2013 Indonesia Basic Health Research). Jakarta. 2014.
5. Permana H, Nugraha GI, Kariadi SHKS. Polimorfisme Gly972Arg Gen IRS-1 dan Cys981Tyr Gen PTPN1 sebagai faktor risiko pada sindrom metabolik dengan riwayat berat bayi lahir rendah (Polymorphism of Gly972Arg Gen IRS-1 and Cys981Tyr Gen PTPN1 as risk factors of metabolic syndrom with the history of low baby birth weight). Majalah Kedokteran Bandung. 2012; 44(3): 170-178.

6. Awad N, Langi YA, Pandelaki K. Gambaran faktor resiko pasien diabetes melitus tipe II di Poliklinik Endokrin Bagian/SMF FK-UNSRAT RSU Prof. Dr. R.D. Kandou Manado periode Mei 2011-Oktober 2011 (Risk factors of type 2 diabetes mellitus patients at Endocrine Polyclinic Prof. Dr.R.D.Kandou Hospital,Manado, May2011-October2011). Jurnal e-Biomedik (eBM) 2013; 1(1): 45-49.

7. Trisnawati S, Widarsa T, Suastika K. Faktor risiko diabetes mellitus tipe 2 pasien rawat jalan di puskesmas wilayah Kecamatan Denpasar Selatan (Risk factor of type 2 diabetes mellitus among patients at outpatient clinic in a South Denpasar public health center). Public Health and Preventive Medicine Archive. 2013; 1(1).

8. Wicaksono RP. Faktor-faktor yang berhubungan dengan kejadian diabetes melitus tipe 2: Studi kasus di Poliklinik Penyakit Dalam Rumah Sakit dr. Kariadi (Skripsi) (Factors associated with the incidence of type 2 diabtes mellitus: A case study at Internal Medicine Polyclinic, dr. Kariadi Hospital (Thesis)). Universitas Diponegoro, 2011. Available at: http://eprints.undip.ac.id/ 37123/1/Radio_P.W.pdf

9. Nuryati S, Madanijah S, Atmarita, et al. Gaya hidup dan status gizi serta hubungannya dengan diabetes melitus pada wanita dewasa di DKI Jakarta (Lifestyle, nutritional status and their association with diabetes mellitus among adult women in Jakarta). Gizi Indonesia. 2009; 32: 117-127.

10. Tsumura K, Hayashi T, Suematsu C, et al. Daily alcohol consumption and the risk of type 2 diabetes in Japanese men. Diabetes Care 1999; 22(9): 1432-1437.

11. Wei M, Gibbons LW, Mitchell TL, et al. Alcohol intake and incidence of type 2 diabetes in men. Diabetes Care 2000; 23(1): 18-22.

12. Suhardi. Preferensi peminum alkohol di indonesia menurut Riskesdas 2007. Buletin Penelitian Kesehatan. 2011; 39(4): 154-164.

13. Jannah M, Riskiyani S, Rahman A. Aspek sosial budaya pada konsumsi minuman beralkohol (tuak) di Kabupaten Toraja Utara (The social culture aspect of alcohol (tuak) used in North Toraja). Universitas Hasanuddin. 2014. Available at: http://repository.unhas.ac.id/ bitstream/ handle/123456789/13081/MIFTAHUL\%20JANNAH. pdf? sequence $=1$

14. Ministry of Health of Indonesia. Laporan Riskesdas 2007 Provinsi Bali (The Report of 2007 Bali Provincial Basic Health Research). Jakarta. 2008.

15. Ministry of Health of Indonesia. Riset Kesehatan Dasar dalam Angka (Riskesdas 2013) Provinsi Bali (Basic Health Research in Numbers (Basic Health Research 2013) Bali Province. Jakarta. 2013.

16. Karangasem District Health Office, Bali Province. Profil kesehatan Kabupaten Karangasem tahun 2012 (The 2012 health profile of Karangasem District). Amlapura. 2012.

17. Karangasem District Health Office, Bali Province. Data surveilans terpadu penyakit tahun 2014 (The 2014 integrated diseases surveillance). Amlapura. 2014.

18. Sudiana IK, Putra IWGAE, Januraga PP, et al. Konsumsi tuak meningkatkan risiko obesitas sentral pada pria dewasa di Karangasem, Bali. Public Health and Preventive Medicine Archive. 2016; 4: 134-142.

19. Nurhikmawati F, Manurung M, Laksmiwati AAIAM. Penggunaan kitosan dari limbah kulit udang sebagai inhibitor keasaman tuak (Use of chitosan sourced from 
shrimp's skin waste as the tuak's acidity regulator). Jurnal Kimia. 2014; 8: 191-197.

20. World Health Organization. WHO STEPS instrument (Core and Expanded): The WHO STEPwise approach to chronic disease risk factor surveillance (STEPS). Geneva. Available at: www.who.int/chp/steps.

21. Chinese University of Hong Kong. Food frequency questionnaire (FFQ): Population-based food consumption survey of the people of Hong Kong. Available at: http://www. cfs. gov.hk/english/programme/programme_firm/ files/ Appendix_B_FFQ_en.pdf

22. World Health Organization. Global physical activity questionnaire (GPAQ): Analysis guide. Geneva. Available at: http://www.who.int/ ncds/surveillance/steps/resources/ GPAQ_Analysis_Guide.pdf.
23. Djousse L, Biggs ML, Mukamal KJ, et al. Alcohol consumption and type 2 diabetes among older adults: The cardiovascular health study. Obesity 2007; 15(7): 1758-1765.

24. Bell RA, Davis EJM, Martin MA, et al. Associations between alcohol consumption and insulin sensitivity and cardiovascular disease risk factors: The insulin resistance and atherosclerosis study. Diabetes Care. 2000; 23: 1630-1636.

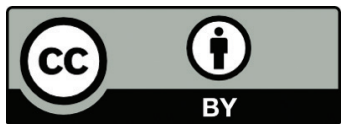

This work is licensed under a Creative Commons Attribution 